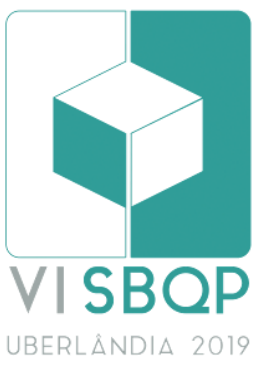

\title{
ARQUITETURA INCLUSIVA: EXPERIÊNCIAS DE PROJETOS COLABORATIVOS
}

\author{
SILVA, Luísa \\ Faculdade Meridional IMED, luisa.projetospredilar@gmail.com \\ DE CESARO, Sara \\ Faculdade Meridional IMED, saradecesaro@hotmail.com \\ MUSSI, Andrea \\ Faculdade Meridional IMED, andrea.mussi@imed.edu.br
}

\begin{abstract}
RESUMO
Este artigo apresenta o uso de projetos colaborativos em arquitetura como forma de inclusão social de Pessoas com Deficiência Visual (PCDV), uma parceria entre a Associação Passofundense de Cegos - APACE (comunidade) e Programa de Pós-graduação Stricto Sensu em Arquitetura e Urbanismo - IMED (Instituição de Ensino Superior). O artigo tem por objetivo descrever dois projetos colaborativos, um realizado com os adultos da associação para a melhoria de um espaço interno e a elaboração de uma proposta de área externa para convívio e lazer. O segundo projeto colaborativo, foi realizado com as crianças da associação para elaboração de um brinquedo, a ser inserido dentro da proposta de melhoria da área interna, e uma adequação de um brinquedo, criado em uma disciplina da graduação em arquitetura e urbanismo, para colocação na área externa. Busca demonstrar a importância de projetos colaborativos como forma de inclusão das PCDV, pois são capazes de aumentar o bem-estar e a autoestima, ao passo que participando efetivamente da criação do ambiente no qual estão inseridos, conseguem sair da zona passiva que normalmente se encontram no que se refere ao processo de projeto em arquitetura.
\end{abstract}

Palavras-chave: Projeto em Arquitetura e Urbanismo. Pessoa com Deficiência Visual. Parâmetros. Projetos Colaborativos. Maquete tátil.

\begin{abstract}
This paper presents the use of collaborative projects in architecture as a form of social inclusion for people with visual impairment, a partnership between the Association of the Blind - APACE (community) and the Stricto Sensu Postgraduate Program in Architecture and Urbanism (IMED). The article aims to describe two collaborative projects, one with the adults of the association for the improvement of an internal space and the elaboration of a proposal for an external area for living and leisure. The second collaborative project was carried out with the children of the association to elaborate a toy, to be inserted within the proposal of improvement of the internal area, and an adaptation of a toy, created in a discipline of graduation in architecture and urbanism, for placement in the external area. Tries to demonstrate the importance of collaborative projects as a way of including the PCDV, as they are able to increase well-being and self-esteem, while effectively participating in the creation of the environment in which they are inserted, they manage to leave the passive zone that normally are in relation to the architectural design process.
\end{abstract}

Keywords: Project in Architecture and Urbanism. Person with Visual Impairment. Parameters. Collaborative Project. Tactile Model.

SILVA, L.; DE CESARIO, S.; MUSSI, A. Arquitetura inclusiva: experiências de projetos colaborativos. In: SIMPÓSIO BRASILEIRO DE QUALIDADE DO PROJETO NO AMBIENTE CONSTRUÍDO, 6., 2019, Uberlândia. Anais... Uberlândia: PPGAU/FAUeD/UFU, 2019. p. 62-74. https://doi.org/10.14393/sbqp19007. 


\section{INTRODUÇÃO}

Segundo Huang e Yu (2013) pessoas cegas ou com algum tipo de comprometimento visual utilizam outros órgãos sensoriais além da visão, como toque e olfato, para registrarem os sinais do ambiente circundante e gerarem memórias para adequada orientação espacial. Dessa forma, elas utilizam as informações que adquirem no espaço para resolver seus problemas de se localizarem.

No que diz respeito à participação das PcDV na arquitetura, Bianchini e Heylighen (2017) afirmam que a deficiência decorre de interações com o ambiente circundante que são passíveis de intervenções estruturais e de projeto, e não inerentemente de níveis de capacidade, estado de saúde ou graus de deficiência associados. Ou seja, as PCDV possuem um grande afastamento no que diz respeito à arquitetura já que, frequentemente, considera-se acessível espaços que apresentam somente soluções para pessoas com dificuldade de mobilidade.

Projetos colaborativos, no entanto, podem se tornar grandes aliados para que as distâncias das PCDV ao processo de projeto sejam diminuídas. Segundo Carneiro, Barros e Zibel (2011) a participação de usuários na concepção de um projeto possibilita discussões aprofundadas sobre as diferentes necessidades para o ambiente. Então, de acordo com as atividades cotidianas se delimita as possibilidades do projeto e são realizadas trocas constantes entre os arquitetos e usuários para o andamento do projeto.

Cavalvanti, Andrade e Silva (2011) defendem o processo de criação compartilhada, construindo projetos coletivamente, como uma maneira de identificar preferências e fortalecer o coletivo. Dessa forma, se aplica a projetos colaborativos arquitetônicos no âmbito de identificar as preferências dos usuários e promover o fortalecimento do coletivo com o ambiente projetado.

O artigo apresentado possui como objeto de estudo, o Projeto Colaborativo (PC), e como objetivo elaborar uma proposta de projeto de melhoria de um ambiente interno e de uma área externa de convivência para a Associação Passofundense de Cegos (APACE). E, de elaborar a proposta de brinquedos infantis a serem colocados nestes dois espaços. Contudo, devido ao grau de importância que os brinquedos a serem elaborados para as crianças nos dois espaços citados possuem, o PC será dividido em duas partes: um com os adultos e um com as crianças.

Importante salientar que a parceria entre a APACE e o Programa de Programa de Pós-graduação Stricto Sensu em Arquitetura e Urbanismo - (IMED) acontece por meio do Grupo de pesquisa Núcleo de Inovação e Tecnologia em Arquitetura e Urbanismo (NITAU). Essa parceria acontece desde 2013, por meio de projetos colaborativos que visam inserir as PCDV no processo de projeto (MUSSI et al., 2016; OLIVEIRA, PORTELLA, MUSSI, 2018; MUSSI et al. 2019).

\section{METODOLOGIA}

O artigo apresentado é de natureza qualitativa, do tipo pesquisa em campo, pois é capaz de extrair dados e informações diretamente da realidade do objeto de estudo. A pesquisa faz uso do PC, que Caixeta e Fabrício (2018) apontam ser uma metodologia eficaz para envolver usuários em um processo 
de projeto que busca compreender e aprender com o usuário a sua expertise. Para a realização das discussões foi escolhido o método de Focus Group (FG) no qual busca, por meio da definição de tópicos norteadores, encaminhar as discussões sobre determinado tema.

A pesquisa subdividi-se em dois projetos colaborativos, realizados em concomitância. O primeiro PC, realizado com os adultos, traz a elaboração de uma proposta de projeto para melhoria de um espaço interno, a sala de espera/recepção, e de uma área externa para convívio e lazer.

O PC com as crianças se trata da elaboração de dois brinquedos, um a ser colocado na sala de espera/recepção e outro na área externa de convívio. Importante ressaltar que o brinquedo da área externa foi elaborado por alunos de graduação em arquitetura e possui possibilidade de alterações que dependerão dos resultados encontrados. Em ambos os projetos colaborativos ocorreram a realização de FG para a obtenção de informações.

Contudo, como se tratam de atividades com peculiaridades distintas, os projetos colaborativos foram separados, conforme demonstra a Figura 1.

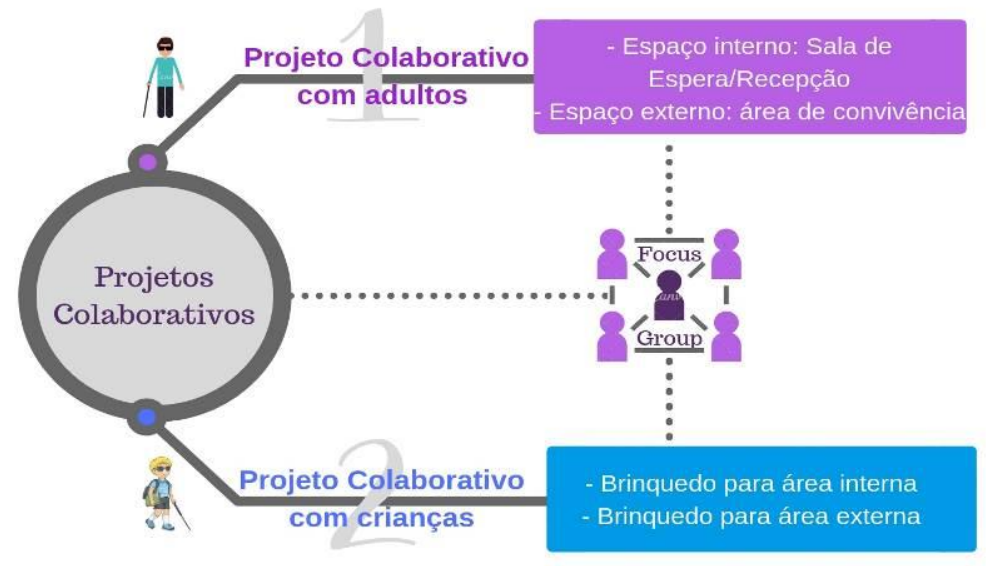

Figura 1 - Infográfico dos projetos colaborativos Fonte: Autores (2019)

Dentre todas as fases realizadas no PC com os adultos (Figura 2), é importante salientar a realização de um FG e a elaboração de uma maquete tátil, elaborada pelas autoras em laboratório de fabricação digital, para experimentação da proposta de projeto.

Os tópicos norteadores propostos pelos moderadores (autoras) foram: "O que se faz no espaço? Funções. Quantas pessoas utilizam? O que é necessário? Quais aspectos precisam melhorar o uso? Piso e mobiliário? ". Para a área de convívio/lazer da área externa foram elencados os seguintes tópicos norteadores: "O que é necessário para que a área externa se torne convidativa para os associados? Que atividades gostariam de realizar nela? Que elementos físicos necessitam ser melhorados para utilização com segurança?". 


\section{Fases do Projeto colaborativo - adultos}

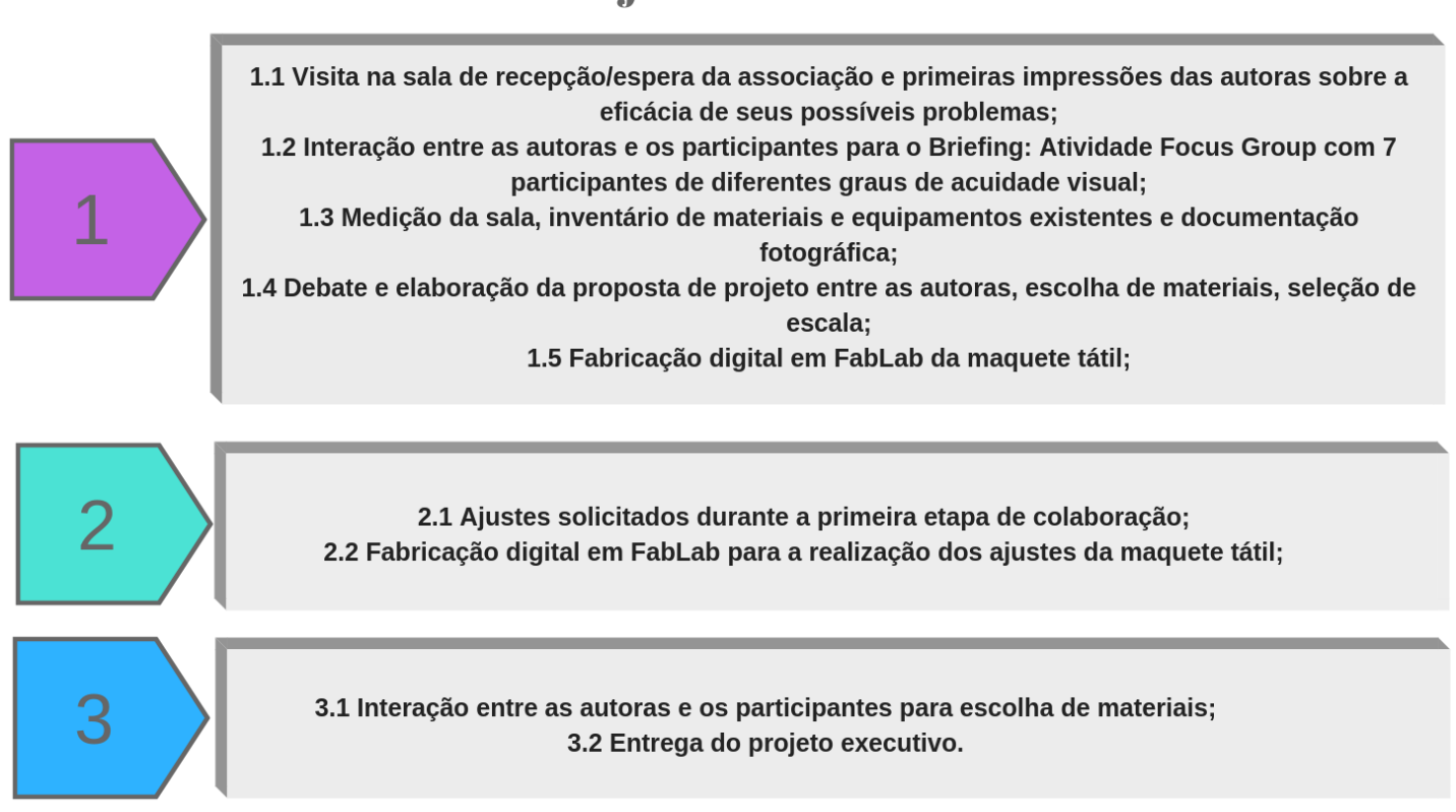

Figura 2 - Infográfico das fases do projeto colaborativo com os adultos Fonte: Autores (2019)

O segundo assunto debatido, durante a atividade de FG realizado no PC com os adultos, foi sobre a necessidade de melhoria da área externa, ou seja, os tópicos norteadores debatidos foram quais atitudes seriam essenciais para que esse espaço pudesse se tornar um ambiente agradável para descontração e para recreação das crianças. Os tópicos norteadores, no entanto, foram: "O que é necessário para que a área externa se torne convidativa para os associados? O que se planeja para ela? As crianças conseguem brincar com segurança? $O$ que seria prazeroso para se fazer no local? Que atividades gostariam de realizar nela? Que elementos físicos necessitam ser melhorados para utilização com segurança? ".

Sendo assim, definidos os tópicos norteadores, estruturou-se os grupos que participariam da atividade, com definição do nível de envolvimento com o problema para cada participante. Foram definidos 7 participantes membros da associação, no grupo etário de 25-50 anos, divididos da seguinte maneira: dois participantes cegos, sendo um deles homem e um deles mulher, quatro participantes com diferentes graus de acuidade visual, sendo um homem e 3 mulheres e uma colaboradora voluntária da associação. Os moderadores foram as autoras.

A dinâmica aconteceu na sala de atividade de leituras da Associação estruturada através dos tópicos norteadores e conforme a conversa avançou ocasionou-se o que Morgan (1997) define como estrutura moderada de funil, no qual à medida que os tópicos gerais surgem, as questões vão se tornando cada vez mais específicas. Com isso, a atividade teve duração de 1 hora e foi gravada para posterior transcrição e análise.

Entre as fases do PC com as crianças, conforme demonstra a Figura 3, foi realizado outro FG para briefing dos brinquedos. Os responsáveis participaram e puderam realizar recomendações importantes em momentos pontuais da atividade. Participaram 5 crianças com seus respectivos responsáveis. 


\section{Fases do Projeto colaborativo - crianças}

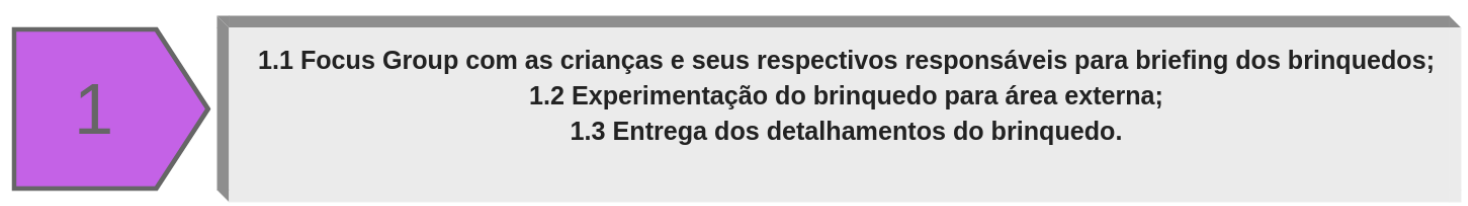

Figura 3 - Infográfico das fases do projeto colaborativo com as crianças

Fonte: Autores (2019)

O PC com as crianças teve como objetivo desenvolver elementos recreativos que explorassem as principais habilidades necessárias ao desenvolvimento e que, ao mesmo tempo, oferecessem oportunidades de interação entre as crianças atendidas pela associação e crianças que, eventualmente, frequentam a associação acompanhando algum familiar. No PC além da atividade de FG também aconteceu a experimentação do brinquedo a ser adaptado, elaborado pelos alunos da graduação.

\section{RESULTADOS}

\subsection{Projeto colaborativo com adultos}

A primeira atividade realizada para a apropriação das necessidades e aspirações para a melhoria da sala de espera/recepção e para a área externa de convívio e lazer da associação foi a atividade do FG (Figura 4).

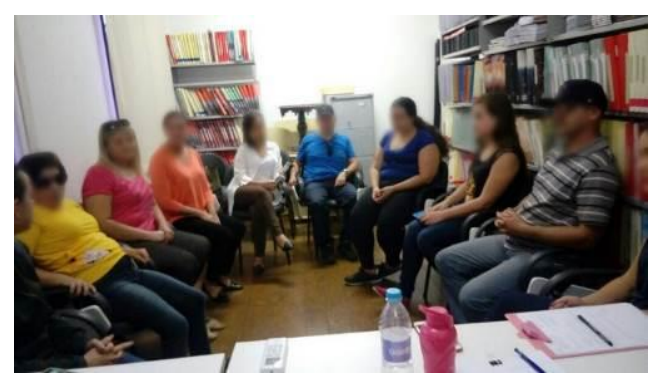

Figura 4. Focus Group com adultos

Fonte: Autores (2019)

Os primeiros tópicos mencionados foram direcionados para a sala de espera/recepção, quais suas necessidades e principais dificuldades encontradas para a utilização efetiva do espaço. Quanto ao piso, as informações transmitidas foram de que o piso não possui nenhum tipo de alerta no acesso à sala de espera/recepção, e que ainda, para maior dificuldade, possui um degrau. Também foi relatado que, devido à associação estar inserida em uma casa antiga cedida pela prefeitura, ela possui um piso com muitas irregularidades. Esse primeiro tópico foi desafiador visto que, embora os participantes tivessem real conhecimento do espaço, foi necessário questioná-los sobre quais as medidas seriam mais interessantes para ajudar não só as PCDV já frequentadoras da associação, mas as novas que poderiam vir a conhecer e necessitar utilizar o espaço. Esse tópico foi de extrema importância para a elaboração da proposta para o piso que teve um projeto definido com diferenciação de cores e texturas. O segundo tópico debateu sobre os móveis existentes na sala: são aconchegantes para a espera entre uma atividade e outra dos associados? A disposição dos móveis atuais é 
correta? Quais seriam os elementos principais para que a sala se torne confortável?

As perguntas dos móveis levaram ao terceiro tópico norteador que tratou sobre a função da sala: qual a principal atividade realizada pelos associados dentro desse espaço? Quantas pessoas o utilizam? Com que frequência? A participante 3, cega desde o seu nascimento, demostrou-se muito insatisfeita com a falta de aconchego da sala devido à falta de poltronas confortáveis, à falta de um local para a disponibilidade de água, café ou outra refeição rápida já que, muitas vezes, precisa esperar mais de 1 hora entre os turnos de suas atividades.

Os participantes em sua maioria concordaram com a afirmativa a respeito, porém, como esperado surgiram questões alheias ao tópico de partida, tais como, o incômodo sentido pelo barulho vindo da rua que atrapalha as aulas de leitura. Tais afirmações levam ao último tópico norteador que trata da satisfação dos usuários com o espaço que, segundo os participantes, não possui nenhum tipo de conforto e pouco espaço que se acentua fruto de uma errônea disposição dos móveis. Sendo assim, todos os tópicos foram debatidos e tiveram as respostas unificadas, como demonstra a Figura 5, para que fossem levadas para avaliação e elaboração da proposta de projeto pelas autoras.

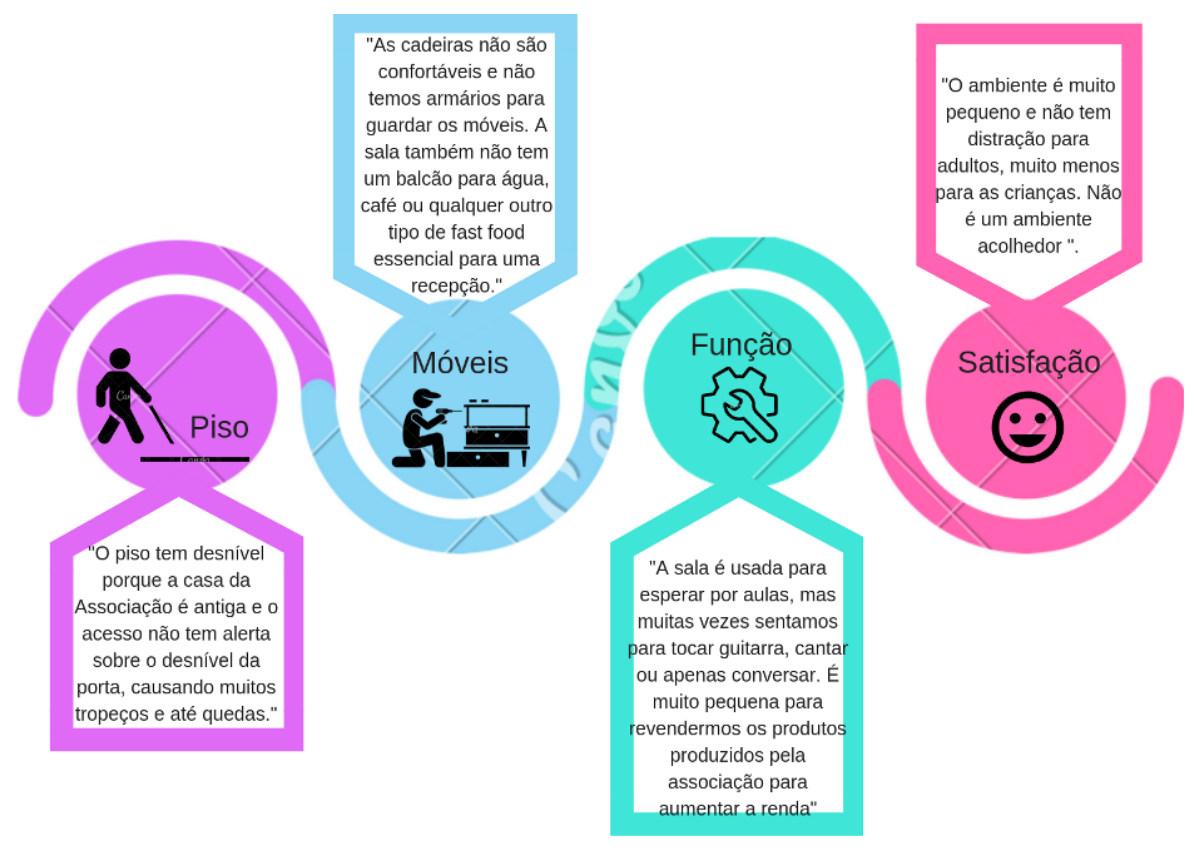

Figura 5. Respostas gerais dos tópicos norteadores no Focus Group Fonte: Autores (2019)

Após todas as atividades que delimitaram as dificuldades e as necessidades expostas pelos participantes, o projeto foi elaborado. As decisões iniciaram-se pelo piso que teve uma proposta de diferentes texturas, com piso carpete na cor azul escura e piso vinílico na cor amarela, que formam um eixo direcional até o corredor de acesso ao restante das salas. Essas cores foram, com testes realizados, definidas pelos participantes baixa visão. Foi definido a necessidade de colocação de piso tátil alerta somente na porta de acesso à sala. Devido ao projeto estar detalhado por vistas, para melhor compreensão, as vistas serão apresentadas separadamente, com suas respectivas explicações. A Figura 6, que representa o Layout da sala de espera/recepção, 
demonstra o eixo direcional formado pela composição de pisos e a numeração das vistas que serão apresentadas a seguir.

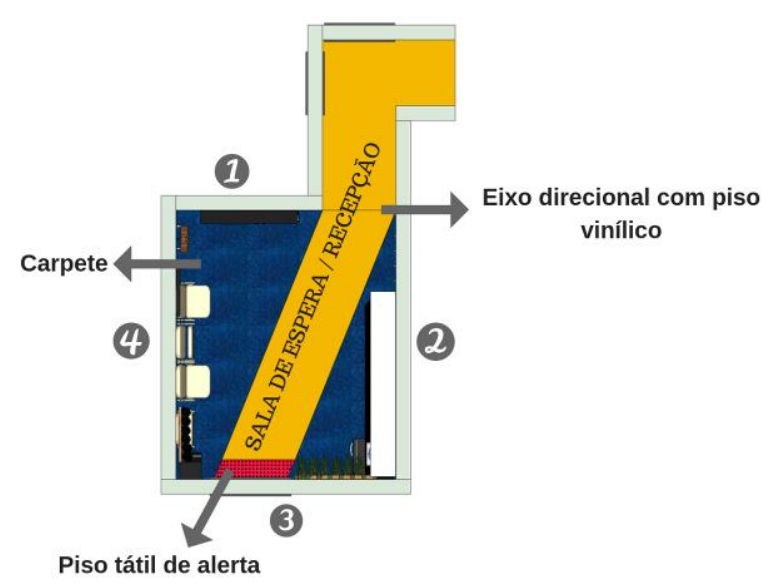

Figura 6. Layout com a descrição das texturas de piso e vistas da sala de
recepção/espera
Fonte: Autores (2019)

Na vista 1 (Figura 6a) foi elaborado um armário para pequenos utensílios, para serem armazenados objetos necessários para as atividades de venda de produtos da associação nos finais de semana, com mesma espessura do brinquedo localizado logo abaixo. As cores das paredes, assim como do piso, foram decididas e testadas pelos participantes durante as atividades do PC. Essas cores foram decididas em conjunto para que não ocasionasse confusão para nenhum associado e para que se adaptasse à todas as diferenças de acuidade visual, sem ocasionar confusão de informações. O brinquedo presente nessa vista do projeto faz parte do PC dois.

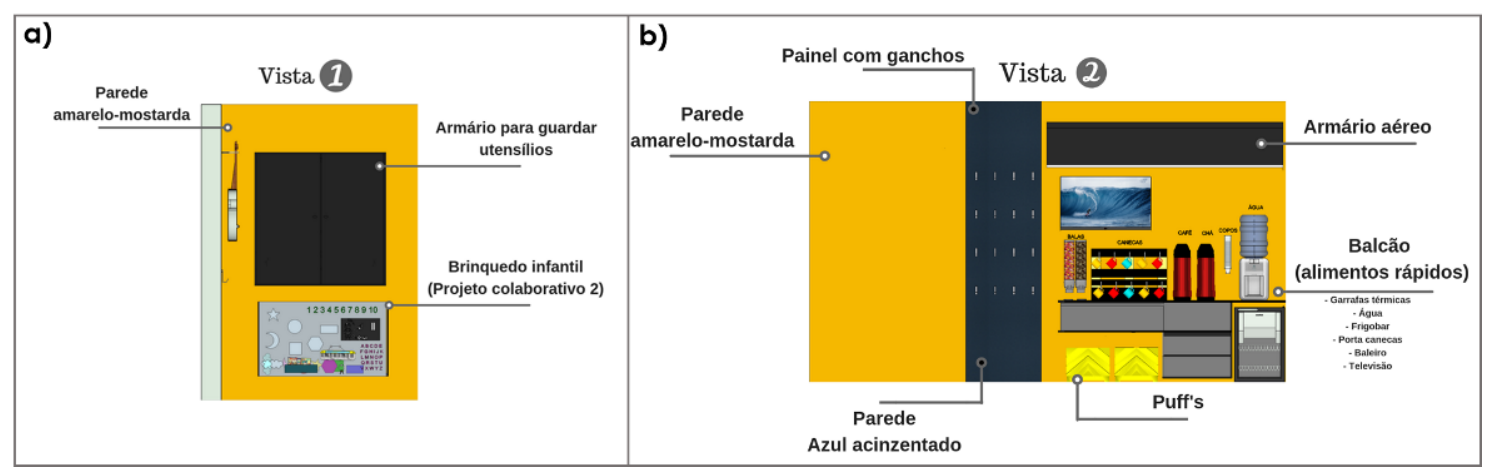

Figura 6. Detalhamento das vistas 1 e 2 da sala de recepção/espera Fonte: Autores (2019)

Na vista 2 (Figura 6b) houve composição de cores para a parede, sendo elaborado um painel na cor azul-acinzentado para a colocação de ganchos, que serão utilizados para pendurar sacolas com produtos vendidos durante os finais de semana, bem como apoio para pendurar bengalas no dia-a-dia. Também houve a elaboração de um balcão para que possa ser oferecido alimentos rápidos como café, água, balas, etc. A colocação desse balcão foi 
uma das mais recorrentes solicitações durante o FG, pois servirá para melhorar o conforto da espera na sala. Todos os itens da bancada foram planejados para terem suas posições fixas, de forma que os usuários, que são PcDV, sempre saibam aonde estão localizados os utensílios. Foram projetados pufes para dar suporte às atividades multifuncionais da sala, como tocar violão e cantar. O armário aéreo será destinado para armazenamento diverso.

Na vista 3 (figura 7a) houve a elaboração de um nicho que será composto por vegetações aromáticas, como alecrim ou hortelã. Pallasmaa (2012), afirma que explorar outras habilidades é de essencial importância para que o espaço arquitetônico seja compreendido como o espaço vivido, que possa transcender a geometria ou mensurabilidade da beleza, para PCDV.

Para o planejamento da vista 4, conforme Figura 7b, foi necessário encontrar soluções para melhorar a eminência de luz, ocasionada por uma janela que ocupa a extensão de quase toda parede, e atrapalha a mobilidade das PCDV que não são completamente cegas. O excesso da incidência de luz ocorrerá por meio do bloqueio de duas folhas da janela existente que acontecerá através de um painel verde, no qual serão colocadas mais vegetações aromáticas, e por meio de uma mesa retrátil que será utilizada aos finais de semana para as atividades de venda de produtos. A mesa foi projetada para que durante a semana possa servir de mural, com papel lousa, para informar aos visitantes as atividades que estão acontecendo. Nessa vista também foi planejado um gancho alto para pendurar um violão e ganchos mais baixos para pendurar casacos. As cadeiras serão retráteis para que os usuários possam sentar-se ao chão e usufruir do piso de carpete, pensado e elaborado para as atividades de canto e violão. Projetou-se uma mesa de canto para que estejam disponíveis panfletos de apresentação para visitantes ou livros em braile.

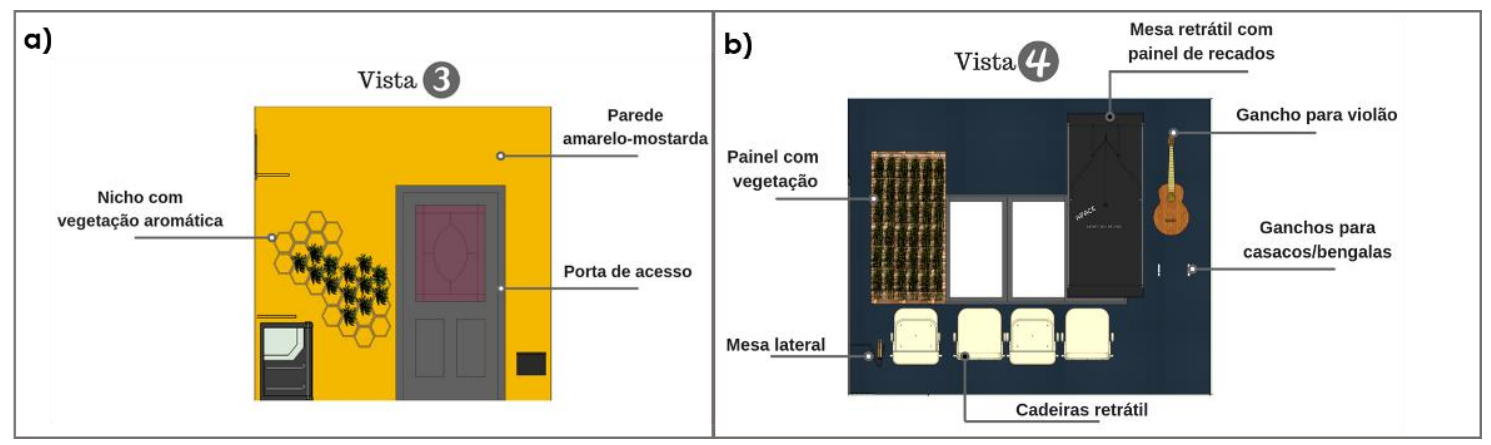

Figura 7. Detalhamento das vistas 3 e 4 da sala de recepção/espera

Fonte: Autores (2019)

Após a elaboração do projeto do interior da sala, iniciou-se a etapa de fabricação da maquete tátil (Figura 8). A confecção aconteceu em laboratório de fabricação digital, com materiais que representassem a textura dos elementos e objetos contidos no projeto e não oferecessem riscos para serem manuseadas pelas PCDV. A maquete foi cortada em cortadora a laser com MDF de 6 milímetros e composta de diferentes tecidos para representar as texturas. 


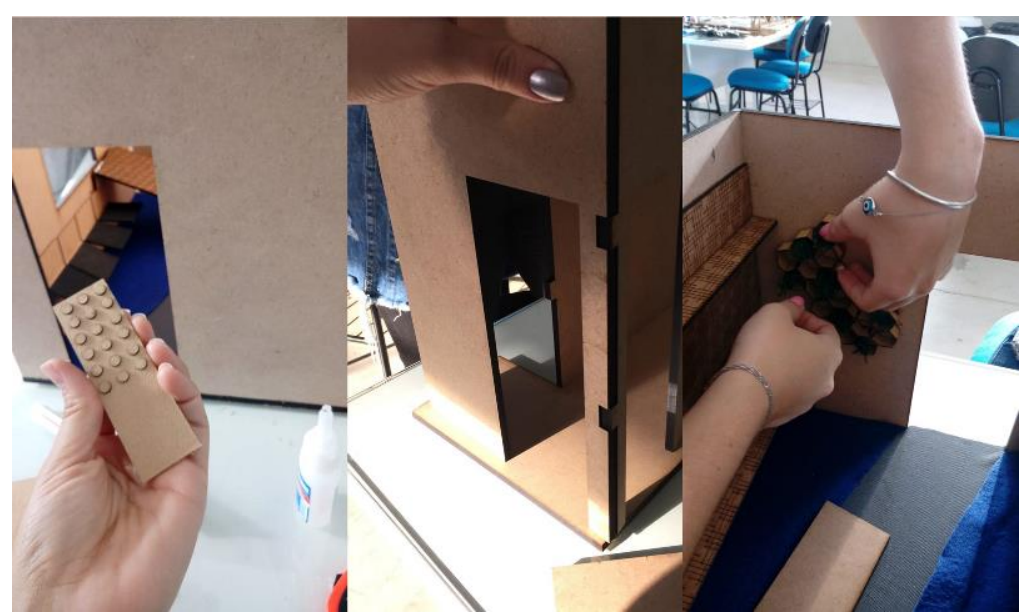

Figura 8. Montagem da maquete tátil em laboratório Fonte: Autores (2019)

A maquete tátil foi apresentada (Figura 9) aos mesmos participantes do FG, que ao manusearem a maquete puderam sentir o estofado das cadeiras retráteis, as diferentes texturas definidas para o piso, a vegetação dos painéis verdes, o piso tátil, bem como, a abertura dos armários, da porta de acesso e a retratibilidade de todos os móveis que foram planejados para serem movimentados. Os participantes gostaram dos resultados e surpreenderam-se com o cuidado e detalhamento para que fossem alcanças todas as solicitações. A sala foi reconhecida com facilidade por todos os participantes, que identificaram rapidamente o acesso, a janela existente e os demais detalhes. Os demais materiais e objetos também foram identificados pelos participantes com facilidade.

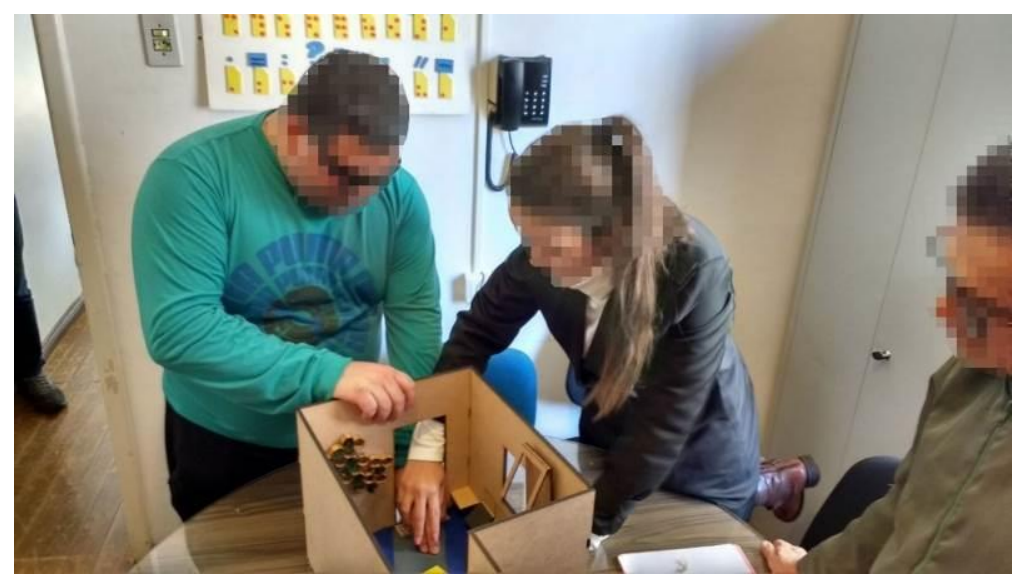

Figura 9. Apresentação da maquete tátil

Fonte: Autores (2019)

No que se refere à área externa, durante o debate dos tópicos norteadores foi possível perceber o comprometimento dos participantes em tentar não somente pensar em seus próprios desejos, mas também buscar elementos que satisfizessem os demais associados que não estavam presentes. Para a proposta da área externa (Figura 10), se fez necessário a composição de pisos para melhor direcionamento dos usuários, e por isso, o eixo direcional seguiu o mesmo padrão da sala de espera/recepção. Para o restante da área externa a proposta é de um piso escuro emborrachado. Essa atitude é uma tentativa de padronizar o piso da sede que atualmente é composto por parquê escuro envelhecido e por uma calçada externa desgastada. 


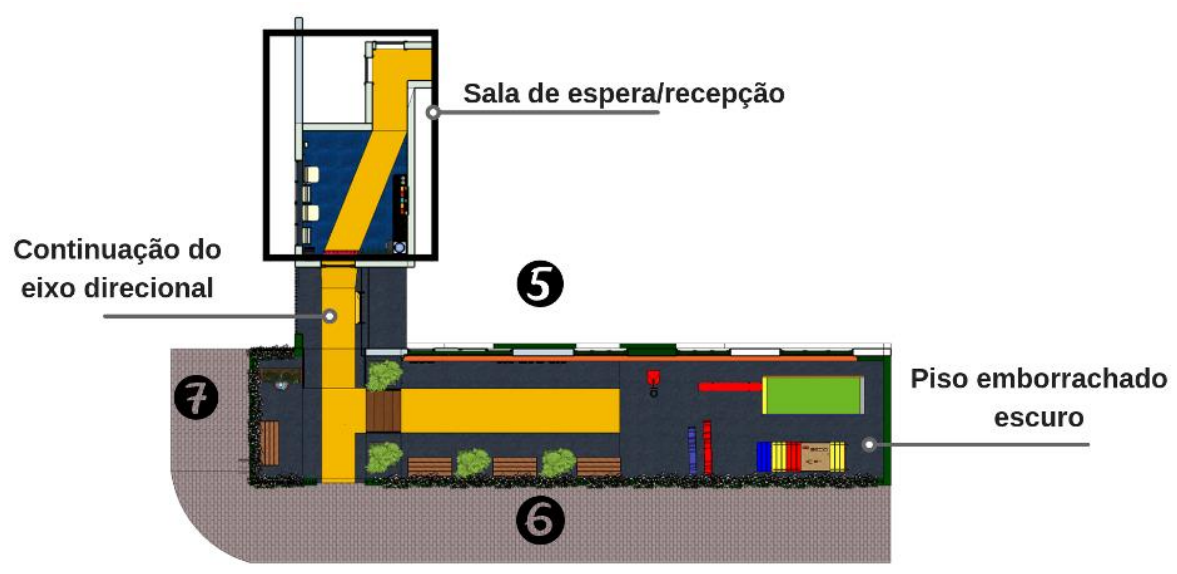

Figura 10. Layout área externa

Fonte: Autores (2019)

Na vista 5 (Figura 1 la) é possível observar a inserção de uma fonte de água como um elemento sonoro que trará acolhimento e aconchego para os usuários. Houve também a implementação de áreas verdes, com a colocação de canteiros e painéis verdes para a plantação de flores e folhas aromáticas. Os brinquedos para área de recreação das crianças foram reaproveitados, somente foi planejado a substituição do escorrega existente pelo brinquedo que faz parte do PC que será apresentado a seguir.
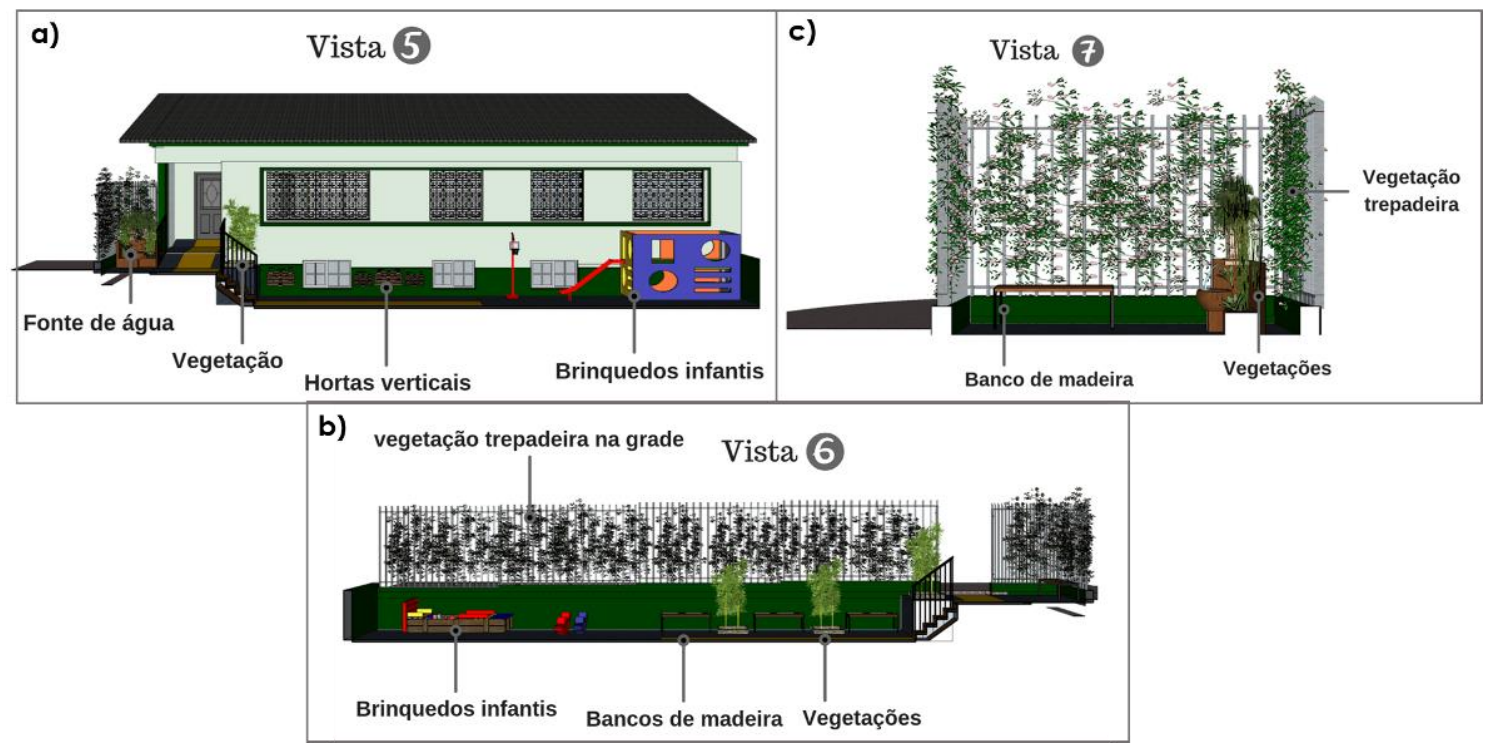

Figura 11. Vistas 5, 6 e 7 desenvolvido para a área externa Fonte: Autores (2019)

Devido às reclamações da falta de segurança, ocasionado pela grande visibilidade que a grade da edificação possui, elaborou-se para a vista 6 (Figura 11 b) um sistema de vegetação de trepadeiras para que se dificulte a visibilidade dos transeuntes da rua ao interior da área de convívio. Na vista 7 (Figura 11c) seguiu-se o projeto com a colocação de bancos de madeira e continuação da vegetação trepadeira na grade.

\subsection{Projeto colaborativo com crianças}

O PC com as crianças teve como objetivo (Figura 15) desenvolver elementos recreativos que explorassem habilidades necessárias ao seu desenvolvimento e que, ao mesmo tempo, ofereçam oportunidades de interação entre as 
crianças atendidas pela APACE e crianças que, eventualmente, frequentam a associação acompanhando algum familiar.

O primeiro brinquedo (Figura 12), elaborado para o espaço interno, busca desenvolver a parte cognitiva da criança com brincadeiras de encaixes de figuras geométricas, elementos sonoros, letras, números e brinquedos diversos fixados por meio de velcro.

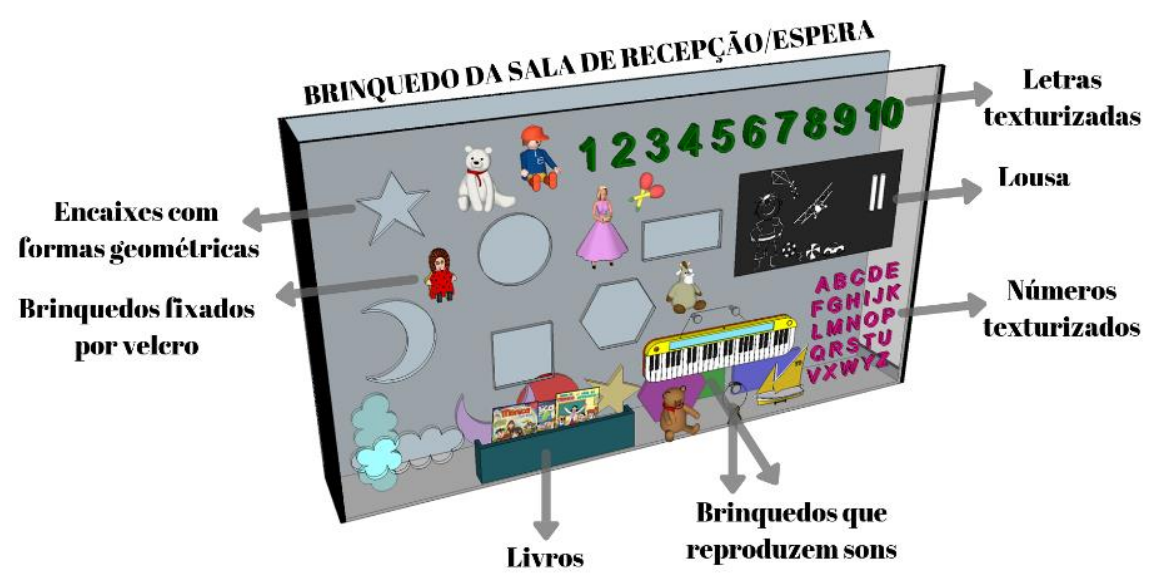

Figura 12. Brinquedo desenvolvido para a sala de recepção/espera Fonte: Autores (2019)

O segundo brinquedo, elaborado na disciplina de Fabricação Digital e Prototipagem Rápida do $4^{\circ}$ semestre de Arquitetura e Urbanismo, teve briefing de uma criança com deficiência visual. $O$ brinquedo foi elaborado durante $a$ disciplina e ao final dela pôde ser fabricado em tamanho real para sua efetiva utilização. Ele encaixou-se perfeitamente ao briefing infantil das crianças da APACE, visto que, de todas as atividades disponíveis em parquinhos aquela que as crianças mais salientaram durante o FG, foi a do escorrega. Na ocasião também foi possível que as crianças experimentassem o brinquedo (Figura 13), juntamente a seus responsáveis, que puderam dizer em que momentos o brinquedo estava perigoso ou quais seriam as possibilidades de melhoria para melhor segurança.

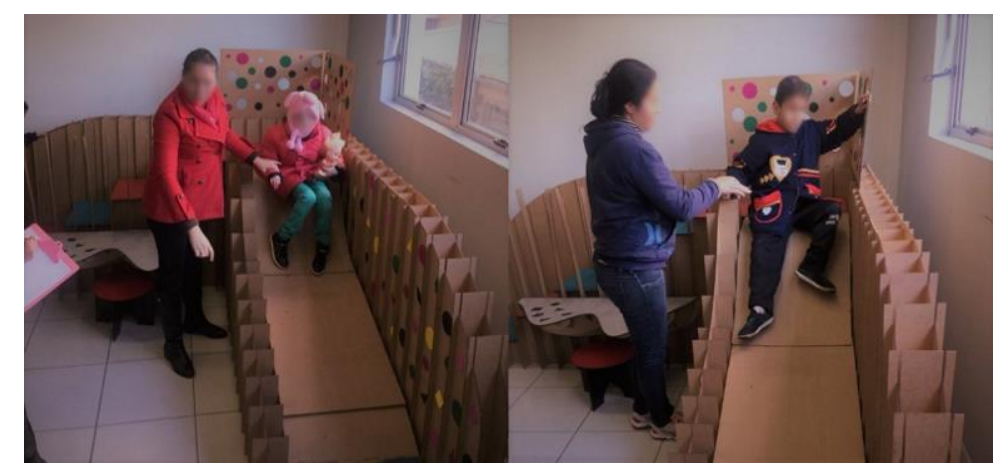

Figura 13. Experimento do Brinquedo pelas crianças

Fonte: Autores (2019)

Os próximos passos desse brinquedo, para sua efetiva inserção ao espaço da associação, são testar o brinquedo com as modificações sugeridas e além do uso de fabricação digital em sua confecção, acrescer automatização com 
programação em arduino, sensores e atuadores, os quais foram implantados em menor escala na primeira versão do protótipo.

\section{CONSIDERAÇÕES FINAIS}

A principal contribuição desse artigo foi apresentar meios de representação que promovam a participação efetiva de PcDV no Processo de Projeto, com o uso de PC que fazem uso de fabricação digital e outras metodologias como FG. Estabelecer uma comunicação comum entre PcDV e projetistas é primordial para viabilizar a colaboração e a interação, para que assim ocorra a característica principal desse processo, a relação entre os atores envolvidos. Representações concretas como a maquete tátil realizada em cortadora a laser, mostrou-se adequada para estabelecer uma linguagem comum de projeto de arquitetura interiores com os adultos, assim como o protótipo do brinquedo em escala real foi propícia para as crianças assistidas por seus responsáveis sugerirem modificações e incrementos projetuais.

\section{AGRADECIMENTOS}

Agradecimentos a Associação Passofundense de Cegos (APACE), ao Programa de Suporte à Pós-Graduação de Instituições de Ensino Particulares / Coordenação de Aperfeiçoamento de Pessoal de Nível Superior - Brasil (PROSUP/CAPES) e ao Núcleo de Inovação e Tecnologia em Arquitetura e Urbanismo (NITAU) do Programa de Pós-graduação em Arquitetura e Urbanismo da Faculdade Meridional (PPGARQ/IMED) pelo apoio recebido a essa pesquisa.

\section{REFERÊNCIAS}

BIANCHIN, M.; \& HEYLIGHEN, A. Just design, Design Studies (2017), https://doi.org/10.1016/j.destud.2017.10.001

CAIXETA, M. C. B. F.; FABRICIO, M. M. Métodos e instrumentos de apoio ao codesign no processo de projeto 111 de edifícios. Ambiente Construído, Porto Alegre, v. 18, n. 1, p. 111-131, jan./mar. 2018. http://dx.doi.org/10.1590/s167886212018000100212

CARNEIRO, G.; BARROS, G.; ZIBEL, C. Design colaborativo de comportamentos para ambientes interativos. V!RUS, São Carlos, n. 6, dezembro 2011 . Disponível em: <http://www.nomads.usp.br/virus/virus06/?sec=4\&item=8\&lang=pt>. Acesso em: 20 abr. 2018.

CAVALCANTI, V.P.; ANDRADE, A. M. Q.; SILVA, G. D. A. Modos de fazer: uma experiência em processo de criação compartilhado e modelo de atuação transdisciplinar na relação entre design e artesanato. V!RUS, São Carlos, n. 6, dezembro 2011. Disponível em:

$<$ http://www.nomads.usp.br/virus/virus06/?sec=4\&item=7\&lang=pt>. Acesso em: 20 abr. 2018.

MORGAN, David L. Focus Groups as Qualitative Research: Planning and research design for Focus Group. London: Sage, 1997. 
HUANG, Chih-hong; YU, Shu-chuan. A Study of Environmental Perception Patterns of the Visually Impaired and Environmental Design. Indoor And Built Environment, [s.l.], v. 22, n. 5, p.743-749, 12 set. 2012. SAGE Publications. http://dx.doi.org/10.1177/1420326x12456317.

MUSSI, A.Q.; ROMANINI, A.; LANTELME, E.; MARTINS, M.S. 2016. Arquitetura inclusiva: a planta tátil como instrumento de projeto colaborativo com portadores de deficiência visual. In: Congreso de la Sociedad Iberoamericana de Gráfica Digital, 20, Buenos Aires, 2016. Anais... Buenos Aires, SiGraDI, 2016, 3 : 387-393. https://doi.org/10.5151/despro-sigradi2016-714

MUSSI, A. Q.; SILVA, T. L.; ZARDO, P.; SILVA, J. L.; PAZINI, E. Z.; FERRI, M.; MOREIRA, $D$. Welfare increase tools for blind and visually impaired people: inclusive design and tactile model. Arquitetura Revista, v. 15, p. 1-14, 2019.

OLIVEIRA, L.; PORTELA, J.; MUSSI, A. Q.; Arquitetura inclusiva: uma experiência de projeto colaborativo para pessoas com deficiência visual. In: V Encontro da Associação Nacional de Pesquisa e Pós-Graduação em Arquitetura e Urbanismo - ENANPARQ. Anais. Salvador, 2018.

PALLASMAA, Juhani. The Eyes Of The Skin: Architecture And The Senses. New Delhi: Third Edition, 2012.

SANOFF, H. Special issue on participatory design. Design Studies, 28 (3), p. 213215, 2007. 